\title{
Astrobiology
}

Astrobiology Manuscript Central: http://mc.manuscriptcentral.com/astrobiology

\section{Chemical Mapping of Proterozoic Organic Matter at Sub-Micron Spatial Resolution}

\begin{tabular}{|c|c|}
\hline Journal: & Astrobiology \\
\hline Manuscript ID: & AST-06-0031 \\
\hline Manuscript Type: & Research Articles (Papers) \\
\hline $\begin{array}{l}\text { Date Submitted by the } \\
\text { Author: }\end{array}$ & 30-May-2006 \\
\hline Complete List of Authors: & $\begin{array}{l}\text { Oehler, Dorothy; NASA - Johnson Space Center, ARES - } \\
\text { Astrobiology Group; Universities Space Research Association, } \\
\text { Division of Space Life Sciences } \\
\text { Robert, François; Muséum National d'Histoire Naturelle, Laboratoire } \\
\text { d'Etude de la Matière Extraterrestre } \\
\text { Mostefaoui, Smail; Muséum National d'Histoire Naturelle, } \\
\text { Laboratoire d'Etude de la Matière Extraterrestre } \\
\text { Meibom, Anders; Muséum National d'Histoire Naturelle, Laboratoire } \\
\text { d'Etude de la Matière Extraterrestre } \\
\text { Selo, Madeleine; Muséum National d'Histoire Naturelle, Laboratoire } \\
\text { d'Etude de la Matière Extraterrestre } \\
\text { McKay, David; NASA - Johnson Space Center, ARES - Astrobiology } \\
\text { Group }\end{array}$ \\
\hline Keyword: & $\begin{array}{l}\text { Biosignatures, Chemical Fossils, Precambrian Fossils, Proterozoic, } \\
\text { Microbial Mats }\end{array}$ \\
\hline
\end{tabular}




\title{
Research Paper
}

\author{
Chemical Mapping of Proterozoic Organic Matter \\ at Sub-Micron Spatial Resolution
}

\author{
DOROTHY Z. OEHLER, ${ }^{1}$ FRANÇOIS ROBERT, ${ }^{2}$ \\ SMAIL MOSTEFAOUI, ${ }^{2}$ ANDERS MEIBOM, ${ }^{2}$ MADELEINE SELO, \\ DAVID S. MCKAY ${ }^{1}$ \\ ${ }^{1}$ Astrobiology Group, ARES \\ NASA - Johnson Space Center \\ Houston, TX 77058, U.S.A. \\ ${ }^{2}$ Laboratoire d'Etude de la Matière Extraterrestre \\ USM 205 / UMS 2679 \\ Muséum National d'Histoire Naturelle \\ 57, rue Cuvier, Paris 75005, FRANCE
}

* To whom correspondence should be addressed: dorothy.z.oehler@nasa.gov

Running Title: NanoSIMS of Proterozoic Organic Matter 


\begin{abstract}
We have used a NanoSIMS ion microprobe to map sub-micron-scale distributions of carbon, nitrogen, sulfur, silicon, and oxygen in organic microfossils and laminae from the $\sim 0.85$ Ga Bitter Springs Formation of Australia. The data provide clues about the original chemistry of the microfossils, the silicification process, and biosignatures of specific microorganisms and microbial communities. Chemical maps of fossil unicells and filaments reveal distinct walland sheath-like structures enriched in $\mathrm{C}, \mathrm{N}$ and $\mathrm{S}$, consistent with their accepted biological origin. Surprisingly, organic laminae, previously considered to be amorphous, also exhibit filamentous and apparently compressed spheroidal structures defined by strong enrichments in $\mathrm{C}, \mathrm{N}$ and $\mathrm{S}$. By analogy to data from the well-preserved microfossils, these structures are interpreted as being of biological origin, most likely representing densely packed remnants of microbial mats. Because the preponderance of organic matter in Precambrian sediments is similarly "amorphous," our findings open a large body of generally neglected material to in situ structural, chemical, and isotopic study. Our results also offer new criteria for assessing biogenicity of problematic kerogenous materials and thus can be applied to assessments of poorly preserved or fragmentary organic residues in early Archean sediments and any that might occur in meteorites or other extraterrestrial samples.
\end{abstract}




\author{
Key words: Biosignatures-Chemical Fossils-Precambrian Fossils- \\ Proterozoic-Microbial Mats.
}

\title{
INTRODUCTION
}

The search for earliest life on Earth has extended to Archean organic remains that are relatively poorly preserved and considerably more difficult to interpret than the delicately permineralized microfossils known from many Proterozoic deposits. Thus, recent efforts have been directed towards finding biosignatures that can help distinguish poorly preserved fragments of microfossils from either pseudofossils or abiotic organic materials that might be formed hydrothermally or in extraterrestrial processes (House et al., 2000; Boyce et al., 2001; Kudryavtsev et al., 2001; Schopf, 2002; Schopf et al., 2002; Cady et al., 2003; García-Ruiz et al., 2003; Hofmann, 2004; Brasier et al., 2005; Rushdi and Simoneit, 2005; Schopf et al., 2005a, b; Skrzypczak et al., 2005).

An exciting area of research in biosignatures involves the developing technology of NanoSIMS. NanoSIMS is SIMS (Secondary Ion Mass Spectrometry) for ultra-fine feature analysis of elemental and isotopic composition. Its resolution approaches $0.05 \mu \mathrm{m}$ for element mapping, which is 10 to 50 times finer than that attainable with conventional SIMS or electron microprobes. Consequently, NanoSIMS has the potential to reveal previously 
unknown, chemical and structural characteristics of sedimentary organic matter (Oehler et al., 2006a, b).

Robert and colleagues were the first to combine NanoSIMS element maps with optical microscopic imagery in an effort to develop a new method for assessing biogenicity (Robert et al., 2005). They showed that the ability to simultaneously map the distribution of 'organic' elements (such as carbon, nitrogen, and sulfur) and compare those element distributions with well recognized, cellularly preserved fossils could provide significant new insights into to the origin of organic materials in ancient sediments.

In the work presented here, we have utilized NanoSIMS to characterize element distributions of spheroidal and filamentous microfossils and associated organic laminae in chert from the $\sim 0.85 \mathrm{Ga}$ Bitter Springs Formation of Australia. Previous work has established preservation of a diverse microbiota in the Bitter Springs Formation (Schopf, 1968; Schopf and Blacic, 1971), and there is no dispute within the scientific community regarding the biogenicity of any of the Bitter Springs structures evaluated in this study. Our NanoSIMS results, therefore, can be used as a guide for assessing the origin of less well understood organic materials that may occur in early Archean samples and in meteorites or other extraterrestrial samples. 


\section{MATERIALS AND METHODS}

A polished thin section of chert from the Ellery Creek locality of the Bitter Springs Formation (Schopf and Blacic, 1971) was used for analysis. Spheroidal (cf. Myxococcoides) and filamentous (cf. Eomycetopsis) microfossils as well as organic laminae were located within the section using optical microscopy. Specimens were selected for NanoSIMS based on quality of preservation and occurrence at the top surface of the thin section (since NanoSIMS penetrates only the top few tens of nanometers of a thin section). The specimens were photographed using $4 \mathrm{x}, 10 \mathrm{x}$ and $40 \mathrm{x}$ dry objectives, in both transmitted and reflected light, and sketch maps were constructed for use with the photographs for locating the structures of interest in the NanoSIMS instrument. Photomicrographic focal series were taken in transmitted light, using a 100x oil immersion lens, spanning focal planes from the top of the thin section to the base of the structures of interest. The thin section was subsequently cleaned to remove all oil by ultrasonication multiple times with reagent grade ethanol. It then was dried in a $60^{\circ} \mathrm{C}$ oven for an hour to drive off all solvents and finally gold-coated.

Chemical maps were produced with the Cameca NanoSIMS 50 of the Muséum National d'Histoire Naturelle in Paris. Using a focused primary beam of $\mathrm{Cs}^{+}$, secondary ions of ${ }^{12} \mathrm{C}^{-},{ }^{12} \mathrm{C}^{14} \mathrm{~N}^{-},{ }^{32} \mathrm{~S}^{-},{ }^{28} \mathrm{Si}^{-}$, and ${ }^{16} \mathrm{O}^{-}$or ${ }^{18} \mathrm{O}^{-}$were sputtered from the sample surface and detected simultaneously (multicollection-mode) in electron-multipliers at a mass-resolving power of $\sim 4500(\mathrm{M} / \Delta \mathrm{M})$. At this mass- 
resolving power, the measured secondary ions are resolved from potential interference. Because nitrogen is detected as $\mathrm{CN}^{-}$, it can only be detected in the presence of carbon. Images were obtained from a pre-sputtered surface area by stepping the primary beam across the sample surface. The primary beam was focused to a spot-size of $\sim 50-100 \mathrm{~nm}$ and the step-size was adjusted so that it was comparable to, but slightly smaller than the size of the primary beam. An electron gun supplied electrons to the sputtered surface during analysis in order to compensate positive charge deposition from the primary beam and minimize charging effects. Follow-up scanning electron microscopy was performed on the JSM 5910LV at Johnson Space Center.

Calibrated N/C atomic ratios were obtained from the measured ${ }^{12} \mathrm{C}^{14} \mathrm{~N}^{-}$and ${ }^{12} \mathrm{C}^{-}$ratios by normalization to a kerogen standard from the Eocene Green River Shale. The kerogen was extracted by standard $\mathrm{HF}-\mathrm{HCl}$ techniques and comprised $\geq 94 \%$ of the insoluble acid residue; it had a known atomic N/C ratio of 0.018 , which was calibrated to ${ }^{12} \mathrm{C}^{14} \mathrm{~N}^{-}$measured under conditions identical to those used for analyzing the Bitter Springs fossils.

The spheroids analyzed are fairly common in the thin section and occur in clusters of a few to $\sim 25$ cells, most commonly between dark brown organic laminae; the cells are typically just under $10 \mu \mathrm{m}$ in diameter and have distinct reticulate walls, 0.3 to $0.5 \mu \mathrm{m}$ thick. The filaments are sinuous hollow tubes and are abundant in the section, occurring intertwined in mat-like layers that grade 
into the dark organic laminae; the filaments are 3 to $5 \mu \mathrm{m}$ in diameter, up to hundreds of microns long, and have somewhat diffuse granular walls, 0.4 to 0.7 $\mu \mathrm{m}$ thick. The organic laminae are planar features comprised of morphologically indistinct organic material, as seen in optical microscopy. In thin section, they appear as strand-like fragments of organic matter that align to form parallel, wavy to crenulate surfaces. The material comprising the laminae varies from morphologically diffuse and semi-transparent to more distinct-bordered and dark brown in color. The laminae occur at intervals of a fraction of a $\mathrm{mm}$ to a few $\mathrm{mm}$, and they have thicknesses from about 5 to $20 \mu \mathrm{m}$.

\section{RESULTS}

NanoSIMS maps of carbon (C) nitrogen (N), sulfur (S), silicon (Si) and oxygen $(\mathrm{O})$, measured as ${ }^{12} \mathrm{C}^{-},{ }^{12} \mathrm{C}^{14} \mathrm{~N}^{-},{ }^{32} \mathrm{~S}^{-},{ }^{28} \mathrm{Si}^{-}$, and ${ }^{16} \mathrm{O}^{-}$or ${ }^{18} \mathrm{O}^{-}$, respectively, and were acquired of spheroidal and filamentous organic microfossils as well as apparently amorphous organic laminae, from a single thin section of the Bitter Springs Formation (Figs. 1-6). Results demonstrate an excellent correspondence between the optical images of the microfossils and the spatial (2-dimensional) distributions of $\mathrm{C}^{-}, \mathrm{CN}^{-}$and $\mathrm{S}^{-}$(Figs. 1-3). Intense sputtering into one sample additionally showed a correspondence between optical microscopic features at a lower focal plan and $\mathrm{C}^{-}, \mathrm{CN}^{-}$and $\mathrm{S}^{-}$maps at a similar focal plane, achieved after sputtering (Fig. 2). Importantly, the host chert matrix is essentially lacking in 
significant $\mathrm{C}^{-}, \mathrm{CN}^{-}$and $\mathrm{S}^{-}$, and these ions are present only in connection with the structures identified as microfossils in optical microscopy.

Ultra-high resolution images show that the $\mathrm{C}^{-}, \mathrm{CN}^{-}$, and $\mathrm{S}^{-}$distributions are identical to one another for both the spheroidal and the filamentous microfossils (Figs. 4-5). The spheroidal microfossils are defined by wall-like structures that consist of distinct globules enriched in $\mathrm{C}^{-}, \mathrm{CN}^{-}$and $\mathrm{S}^{-}$(Fig. 4). In contrast, the filamentous microfossils appear to consist of more diffuse, irregular and "less packaged" material enriched in $\mathrm{C}^{-}, \mathrm{CN}^{-}$, and $\mathrm{S}^{-}$(Fig. 5). These observations are likely to reflect differences in the biological precursors of the two types of microfossils: the spheroidal microfossils comprising remnants of actual cell walls and the filamentous forms probably representing remnants of extracellular mucilaginous sheaths that are common to filamentous cyanobacteria.

Surprisingly, the $\mathrm{Si}^{-}$and $\mathrm{O}^{-}$maps also appear to reflect the morphology of the microfossils (Figs. 1, 3, 4), even though some $\mathrm{Si}^{-}$and $\mathrm{O}^{-}$yields are detected from the host chert $\left(\mathrm{SiO}_{2}\right)$ as well (Fig. 4F). The general correspondence of high $\mathrm{Si}^{-}$and $\mathrm{O}^{-}$yields with the microfossils may be ascribed to 1) a matrix effect, in which secondary $\mathrm{Si}^{-}$and $\mathrm{O}^{-}$yields are enhanced in organic-rich regions and/or 2) the silicification process, whereby Si-rich phases have nucleated on organic surfaces during permineralization (Oehler and Schopf, 1971; J. Oehler, 1976; Benning et al., 2002; Toporski et al., 2002). 
However, in greater detail, the $\mathrm{Si}^{-}$and $\mathrm{O}^{-}$yields display interesting deviations from the distributions of $\mathrm{C}^{-}, \mathrm{CN}^{-}$, and $\mathrm{S}^{-}$: In the spheroids, the $\mathrm{Si}^{-}$ appears to have a more open texture than is apparent in the $\mathrm{C}^{-}$map (cf. Figs. 4A and $\mathrm{B}$ ) and in high resolution, the globules of $\mathrm{Si}^{-}$are seen to alternate with globules of $\mathrm{C}^{-}$(Figs. 4E-F); in the filaments, $\mathrm{Si}^{-}$and $\mathrm{O}^{-}$distributions appear to be thicker and more continuous than the simultaneously collected $\mathrm{C}^{-}, \mathrm{CN}^{-}$, or $\mathrm{S}^{-}$ions (Figs. 5B-F).

The NanoSIMS elemental maps of the organic laminae exhibit relationships among $\mathrm{C}^{-}, \mathrm{CN}^{-}, \mathrm{S}^{-}, \mathrm{Si}^{-}$, and $\mathrm{O}^{-}$similar to those observed in the spheroids and filaments, and images show densely packed structures reminiscent of the filamentous microfossils and collapsed spheroids (Fig. 6).

$\mathrm{CN}^{-} / \mathrm{C}^{-}$ratios of the spheroids, filaments, and laminae were measured in multiple localities on the NanoSIMS maps. Results show major differences in both absolute values and ranges (Table 1).

\section{DISCUSSION}

For spheroidal and filamentous microfossils, the NanoSIMS $\mathrm{C}^{-}$and $\mathrm{S}^{-}$ distributions are virtually identical to each other and to the $\mathrm{CN}^{-}$distributions, and a one-to-one correspondence exists with optical microscopic images (Figs. 1-5). This suggests that all three elements (carbon, nitrogen, and sulfur) are primarily remnants of biogenic organic matter. The size, shape, texture, and nature of the 
boundaries of the nanoscale remnants of $\mathrm{C}, \mathrm{N}$, and $\mathrm{S}$ of the filaments and spheroids may constitute biosignatures for sedimentary remnants of these Proterozoic microorganisms.

Nitrogen is a good indicator of organic material because it is common in organic matter but rare in rock-forming minerals. Because nitrogen commonly derives from biological fixation processes, it additionally can be an indicator of biological activity. While some chemical reactions might produce abiotic organics with nitrogen under certain hydrothermal or extraterrestrial conditions (Brearley, 2003; Ueno et al., 2004; Remusat et al., 2005), nitrogen is most likely to be an indicator of biogenicity in sedimentary rocks.

The $\mathrm{S}^{-}$probably represents a mixture of originally organic sulfur with sulfur incorporated during early diagenesis by the common process of sulfurization (Kohnen et al., 1989; Eglinton et al., 1993; Werne et al., 2000; Brocks and Summons, 2003). Given the low metamorphic grade of the Bitter Springs Formation (Schopf et al., 2005b), the added sulfur is unlikely to have been derived from thermochemically produced $\mathrm{H}_{2} \mathrm{~S}$ or volcanic sources. Therefore, the sulfur, although partially secondary, is nevertheless likely to be an indicator of microbial activity.

$\mathrm{N} / \mathrm{C}$ ratios determined for the different structures range over two orders of magnitude and such large variations are likely to be significant (Table 1), although we caution that the N/C results are preliminary. There are two types of 
instrumental fractionation between $\mathrm{CN}^{-}$and $\mathrm{C}^{-}$(referred to as "matrix effects") that might affect measured $\mathrm{CN}^{-} / \mathrm{C}^{-}$and calibrated $\mathrm{N} / \mathrm{C}$ ratios. These can occur because 1) kerogen comprising the microfossils and organic laminae is measured in its matrix of silica while the standard was measured in purified acid extracts and 2) the standard is a type I kerogen (i.e. rich in aliphatic chains) whereas kerogen in a nearly one billion year old chert is likely to be much more aromatic. However, such matrix effects cannot account for the large (two-orders of magnitude) variation among the measured $\mathrm{CN}^{-} / \mathrm{C}^{-}$ratios of the different Bitter Springs structures, and so this variation is likely to be real.

In addition, the 2 sigma error for the $\mathrm{CN}^{-} / \mathrm{C}^{-}$of the Green River Shale kerogen standard includes the statistical ion counting and the reproducibility determined by measuring four different locations on the standard; that is $\mathrm{CN}^{-} / \mathrm{C}^{-}=$ $0.023 \pm 0.009$ (2 sigma). 2 sigma errors reported for $\mathrm{CN}^{-} / \mathrm{C}^{-}$measured in multiple locations in each type of Bitter Springs structure would include similar effects (Table 1). While the systematic error on the absolute N/C ratio of the standard is $\pm 30 \%(\mathrm{~N} / \mathrm{C}=0.018 \pm 0.067)$, we are most interested in this paper in the statistical significance of N/C variations among the different Proterozoic structures, and thus, the systematic error of the standard was not taken into account. In summary, while the statistical error on the standard can be used for precise comparisons with statistical errors determined for measured $\mathrm{CN}^{-} / \mathrm{C}^{-}$of 
Bitter Springs structures, the absolute calibrated N/C atomic ratios determined for the structures should be regarded as semi-quantitative estimates.

The $\mathrm{CN}^{-} / \mathrm{C}^{-}$ratios of the filaments are significantly lower (0.02 to 0.04$)$ than the ratios of the spheroids $(0.12-0.22)$. This difference is unlikely to be attributable to subtle diagenetic differences (since all structures are from the same thin section) and there is no evidence of hydrothermal activity or meteoritic contribution which could account for abiotic formation of organic compounds. Thus, the large disparity in the $\mathrm{CN}^{-} / \mathrm{C}^{-}$ratios would seem likely to reflect original differences in the biological precursor materials. This conclusion would be consistent with a mainly exopolysaccharide precursor for the sheath-like material defining the filaments and a peptidoglycan precursor (with much higher expected nitrogen content) for the wall-like material defining the spheroids.

Similarly, a disparity in the original chemistry of the two types of microfossils may explain the apparently thicker and more continuous pattern of silicification in the filaments compared to that in the spheroids ( $c f$. Figs. 5B-F and Fig. 4A, B, E, F). If the filamentous forms are remnants of mucilaginous sheaths, then their originally exopolysaccharide chemistry may have promoted more extensive silicification (by a combination of permeation and encrustation) than occurred on the peptidoglycan of the walls of the spheroids. This possibility is suggested by artificial permineralization studies in which laboratory-fossilized microbial filaments with sheaths were both encrusted and permeated by silica 
(Oehler, 1976) and it would be supported further by a recent studies showing that active permineralization favors exopolysaccharides of cyanobacterial sheaths (Kyle et al., 2004; Kyle et al., 2005).

Surprisingly, the organic laminae exhibit filamentous and apparently compressed spheroidal structures defined by strong enrichments in $\mathrm{C}, \mathrm{N}$ and $\mathrm{S}$ and having size and thickness reminiscent of the well preserved microfossils (Fig. 6). Thus, these structures are interpreted as most likely representing densely packed remnants of microbial mats. This conclusion is consistent with the generally accepted view that such laminae are derived from biological precursors that are simply less well preserved than the optically recognizable filaments and spheroids. Since obvious microfossils were not apparent within the laminae using either optical microscopy or SEM (Fig. 7), this result also demonstrates the potential of NanoSIMS to reveal new structure in kerogenous organic materials that were presumed to be generally amorphous.

$\mathrm{CN}^{-} / \mathrm{C}^{-}$ratios and calibrated $\mathrm{N} / \mathrm{C}$ values for the laminae display higher absolute values and a much greater range than equivalent values from the individual spheroids and filaments (Table 1). The higher absolute values may reflect greater degradation in the laminae resulting in increased $\mathrm{CN}^{-} / \mathrm{C}^{-}$values through oxidation of organic carbon and/or addition of nitrogen by microbial nitrification; such degradation also could account for the relatively poor state of preservation in the laminae, as noted above. The large range in $\mathrm{CN}^{-} / \mathrm{C}^{-}$values 
may suggest that the laminae contain a mixture of microbial constituents, perhaps including filaments and spheroids similar to the well preserved microfossils, other microbial constituents of the ecosystem (e.g., Des Marais, 2003), and possible remnants of a biofilm that formed on the microbial mat during its decline and burial. This interpretation is consistent with the above conclusion (from structural relationships alone) that the laminae are comprised of degraded remains of a microbial mat community.

Modern bacteria have N/C ratios ranging from 0.15 to 0.28 (Fagerbakke et al., 1996; Fukuda et al., 1998) and these values are considerably higher than those from either the individual microfossils or the laminae (overall range of 0.0046 to 0.023; Table 1). However, the $\mathrm{N} / \mathrm{C}$ ratios from the laminae $(0.00276$ to 0.023$)$ are within the range of values reported in bulk kerogen samples from a variety of Precambrian cherts (0.0015 to 0.03; Beaumont and Robert, 1999). The ranges for the kerogen and laminae probably represent a combination of 1) mixtures of precursor organisms, 2) early diagenetic changes to original N/C ratios, and 3) microbial degradation. Indeed, a large range in N/C ratios, such as we have observed in the organic laminae, may be a characteristic, and thus a biosignature, of a degraded biological community. 


\section{CONCLUSIONS}

Our results demonstrate that in situ elemental composition of Proterozoic microfossils can be mapped and quantified with NanoSIMS at a spatial resolution of about $50 \mathrm{~nm}$. Results provide new information regarding original chemistry, silicification, and possible biosignatures for specific Proterozoic microorganisms and remnants of microbial communities. In addition, NanoSIMS images of organic laminae previously thought to be amorphous reveal structures suggestive of densely packed remnants of microorganisms. These results are particularly notable, as the preponderance of organic matter in sedimentary rocks of any age occurs as similarly "amorphous," fragmentary remains, even in deposits with coexisting, well preserved microfossils. Therefore, it appears that NanoSIMS will provide insight into a large body of generally neglected material, and results provide impetus for studying poorly preserved fragments of organic material, such as may occur in some of the earliest Archean samples on Earth and possibly in meteorites or other extraterrestrial materials.

Future work will aim at characterization of microfossils and organic fragments in Precambrian sedimentary rocks of varying ages, depositional environments, and lithologies. Key to selection of structures for this characterization will be their undisputed biogenicity, so that results can be used as a guide to interpreting less well preserved, problematic materials. In situ stable isotope analyses from NanoSIMS will be added and may provide additional 
criteria for distinguishing biologically produced organic matter from that produced by abiotic mechanisms (e.g., $\delta^{15} \mathrm{~N}$ values of Precambrian kerogens generally are distinct from $\delta^{15} \mathrm{~N}$ of primitive organics in interplanetary dust particles and carbonaceous chondrites; Beaumont and Robert, 1999; Floss et al., 2004; Remusat et al., 2005).

Thus, the new elemental and isotopic data obtainable with NanoSIMS will add significantly to the repository of biosignatures that can be used to assess the origin of organic remnants that occur in some of the Earth's oldest rocks, in Martian meteorites (e.g., McKay et al., 2006; Gibson et al., 2006), and that may be found in extraterrestrial samples collected during future missions. 


\section{ACKNOWLEDGEMENTS}

We thank NASA-Johnson Space Center (JSC) and Centre National de la Recherche Scientifique (CNRS) for support. We are also grateful to Dr. Jochen Brocks (Australian National University) for suggestions and comments on the manuscript, Dr. Craig Schwandt and Ms. Georg Ann Robinson (JSC) for assistance with SEM, and Dr. Malcolm Walter (Australian Centre for Astrobiology) for encouragement and advice. This work was partially supported by a PPNP grant from the French government to the Muséum National d'Histoire Naturelle, Laboratoire d'Etude de la Matière Extraterrestre and a NASA grant NRA-03-OSS-01-EXOB to Dr. David S. McKay. 


\section{REFERENCES}

Beaumont, V. and Robert, F. (1999) Nitrogen isotope ratios of kerogens in Precambrian cherts: a record of the evolution of atmosphere chemistry? Precambrian Res. 96, 63-82.

Bennett, B. and Love, G.D. (2000) Release of organic nitrogen compounds from kerogen via catalytic hydropyrolysis. Geochem. Trans. 10,

Benning, L.G., Phoenix, V., Yee, N., Tobin, J.J., Konhauser, K.O., and Mountain, B.W. (2002) Molecular characterization of cyanobacterial cells during silicification: a synchrotron-based infrared study. Geochemistry of the Earth's Surface 6, 259-263.

Boyce, C.K., Hazen, R.M., and Knoll, A.H. (2001) Nondestructive, in situ, cellular-scale mapping of elemental abundances including organic carbon in permineralized fossils. Proc. Natl. Acad. Sci. USA 98 (11), 5970-5974.

Brasier, M.D., Green, O.R., Lindsay, J.F., McLoughlin, N., Jephcoat, A.P. Kleppe, A,K. Press, M., Steele, A., and Stoakes, C. (2005) Critical testing of Earth's oldest putative fossil assemblage from the $3.5 \mathrm{Ga}$ Apex chert, Chinaman Creek, Western Australia. Precambrian Res. 140, 55-102.

Brearley, A.J. (2003) Ubiquitous nanophase Fe, Ni carbides in Murchison finegrained rims: Possible relicts of Nebular Fischer-Tropsch reactions [abstract 5262]. $66^{\text {th }}$ Annual Meteoritical Society Meeting, The Meteoritical Society 2003 Meeting, Munster, Germany. 
Brocks, J.J. and Summons, R.E. (2004) Sedimentary hydrocarbons, biomarkers for early life. In Treatise on Geochemistry Vol. 8, Biogeochemistry, edited by W. H. Schlesinger, Elsevier, Oxford, pp. 63-115.

Cady, S.L., Farmer, J.D., Grotzinger, J.P., Schopf, J.W., and Steele, A. (2003) Morphological biosignatures and the search for life on Mars. Astrobiology 3 (2), 351-368.

Des Marais, D.J. (2003) Biogeochemistry of hypersaline microbial mats illustrates the dynamics of modern microbial ecosystems and the early evolution of the biosphere. Biol. Bull. 204, 160-167.

Eglinton, T.I., Irvine, J.E., Vairavamurthy, A., Zhou, W., and Manowitz, B. (1993) Formation and diagenesis of macromolecular organic sulfur in Peru margin sediments. Org. Geochem. 22 (3-5), 781-799.

Fagerbakke, K.M., Heldal, M. and Norland, S. (1996) Content of carbon, nitrogen, oxygen, sulfur and phosphorus in native aquatic and cultured bacteria. Aquatic Microbial Ecology, 10 (1), 15-27.

Floss, C. and Stadermann, F.J. (2005) NanoSIMS D/H imaging of isotopically primitive interplanetary dust particles [abstract 1423]. In $36^{\text {th }}$ Lunar and Planetary Science Conference Abstracts [CD-ROM], LPI Contribution No. 1234, Lunar and Planetary Institute, Houston. 
Fukuda, R, Ogawa, H., Nagata, T., and Koike, I. (1998). Direct determination of carbon and nitrogen contents of natural bacterial assemblages in marine environments. Appl. Environ. Microbiol. 64 (9), 3352-3358.

García-Ruiz, J.M., Hyde, S.T., Carnerup, A.M., Christy, A.G., Van Kranendonk, M.J., and Welham, N.J. (2003) Self-assembled silica-carbonate structures and detection of ancient microfossils. Science 302, 1194-1197.

Gibson, E.K. Jr., Clemett, S.J., Thomas-Keprta, K L., McKay, D.S., Wentworth, S.J., Robert, F., Verchovsky, A.B., Wright, I.P., Pillinger, C.T., Rice, T., and Van Leer, B. (2006) Observation and analysis of in situ carbonaceous matter in Nakhla: Part II [abstract 2039]. In $37^{\text {th }}$ Lunar and Planetary Science Conference Abstracts [CD-ROM], LPI Contribution No. 1303, Lunar and Planetary Institute, Houston.

Gillaizeau, B., Behar, F., Derenne, S, and Largeau, C. (1997) Nitrogen fate during laboratory maturation of a type I kerogen (Oligocene, Turkey) and related algaenan: Nitrogen mass balances and timing of $\mathrm{N}_{2}$ production versus other gases. Energy Fuels 11 (6), 1237-1249.

Hofmann, H.J. (2004) Archean microfossils and abiomorphs. Astrobiology 4 (2), $135-136$.

House, C.H., Schopf, J.W., McKeegan, K.D., Coath, C.D., Harrison, T M., and Stetter, K.O. (2000) Carbon isotopic composition of individual Precambrian microfossils. Science 28 (8), 707-710. 
Kohnen, M.E.L., Sinninghe Damste, J.S, Ten Haven, H.L., and De Leeuw, J.W. (1989) Early incorporation of polysulphides in sedimentary organic matter. Nature 341, 640-641.

Kudryavtsev, A.B., Schopf, J.W., Agresti, D.G., and Wdowiak, T.J. (2001) In situ laser-Raman imagery of Precambrian microscopic fossils. Proc. Natl. Acad. Sci. USA 98 (3), 823-826.

Kyle, J. E., Paul A. Schroeder, P.A., Crow, D., Romanek, C. (2004) Evidence for biomineralization and preservation of microorganisms in siliceous sinter deposits from the Uzon caldera, Kamchatka, Russia. Abstract \#76327, Paper \#204-7, GSA Abstracts with Programs 36 (5), 474.

Kyle, J. E., Paul A. Schroeder, P.A., Livi, K. (2005) Evidence of microbial framboidal pyrite formation in a terrestrial hot spring. Abstract \#92103, Paper \#86-2, GSA Abstracts with Programs, 37 (7), 205.

McKay, D.S., Clemett, S J., Thomas-Keprta, K.L., Wentworth, S.J., Gibson, E. K., Robert, F., Verchovsky, A. B.., Pillinger, C. T., Rice, T., and Van Leer, B. (2006) Observation and analysis of in situ carbonaceous matter in Nakhla: Part I [abstract 2251]. In $37^{\text {th }}$ Lunar and Planetary Science Conference Abstracts [CD-ROM], LPI Contribution No. 1303, Lunar and Planetary Institute, Houston.

Oehler, D.Z., Mostefaoui, S., Meibom, A., Selo, M., McKay, D.S., and Robert, F. (2006a) "Nano" morphology and element signatures of early life on Earth: A 
New Tool for Assessing Biogenicity [abstract 1067]. In 37 $7^{\text {th }}$ Lunar and Planetary Science Conference Abstracts [CD-ROM], LPI Contribution No. 1303, Lunar and Planetary Institute, Houston.

Oehler, D.Z., Mostefaoui, S., Meibom, A., Selo, M., McKay, D.S., and Robert, F. (2006b) NanoSIMS reveals new structural and elemental signatures of early life [abstract 11]. Astrobiology Science Conference 2006, Washington D.C.

Oehler, J.H. and Schopf, J.W. (1971) Artificial microfossils: Experimental studies of permineralization of blue-green algae in silica. Science 174, 12291231.

Oehler, J.H. (1976) Experimental studies in Precambrian paleontology: Structural and chemical changes in blue-green algae during simulated fossilization in synthetic chert. Geol. Soc. Am. Bull. 87, 117-129.

Remusat, L., Derenne, S., Robert, F., and Knicker, H. (2005) New pyrolitic and spectroscopic data on Orgueil and Murchison insoluble organic matter: A different origin than soluble? Geochim. Cosmochim. Acta 69 (15, 3919-3932.

Robert, F., Selo, M., and Skrzypczak, A. (2005) NanoSIMS images of Precambrian fossil cells [abstract 1314]. In $36^{\text {th }}$ Lunar and Planetary Science Conference Abstracts [CD-ROM], LPI Contribution No. 1234, Lunar and Planetary Institute, Houston. 
Rushdi, A.I. and Simoneit, B.R.T. (2005) Abiotic synthesis of organic compounds from carbon disulfide under hydrothermal conditions. Astrobiology 5 (6), 749769.

Schopf, J.W. (1968) Microflora of the Bitter Springs Formation, Late Precambrian, central Australia. J. Paleontol. 42 (3), 651-668.

Schopf, J.W. (2002) Geochemistry and submicron-scale structure of individual Precambrian microfossils [paper 67-2]. In GSA Annual Meeting Abstracts 2002, Geological Society of America, Denver, CO.

Schopf, J.W. and Blacic, J.M. (1971) New Microorganisms from the Bitter Springs Formation (Late Precambrian) of the north-central Amadeus Basin, Australia. J. Paleontol. 45 (6), 925-961.

Schopf, J.W., Kudryavtsev, A.B., Agresti, D.G., Wdowiak, T.J. and Czaja, A.D., (2002) Laser Raman imagery of Earth's earliest fossils. Nature 416, 73-76.

Schopf, J.W., Kudryavtsev, S.B., and Tripathi, A. (2005a) Three dimensional optical and chemical imagery of Precambrian microscopic fossils [abstract 528]. NASA Astrobiology Institute 2005 Biennial Meeting, Boulder, CO.

Schopf, J.W., Kudryavtsev, A.B., Agresti, D.G., Czaja, A.D., and Wdowiak, T.J. (2005b) Raman imagery: new approach to assess the maturity and biogenicity of permineralized Precambrian fossils. Astrobiology 5(3), 333-371.

Skrzypczak, A., Derenne, S., Binet, L., Gourier, D., and Robert, F. (2005) Characterization of a 3.5 billion year old organic matter: Electron 
paramagnetic resonance and pyrolysis GC-MS. Tools to assess syngeneity and biogenicity [abstract 1351]. In $36^{\text {th }}$ Lunar and Planetary Science Conference Abstracts [CD-ROM], LPI Contribution No. 1234, Lunar and Planetary Institute, Houston.

Toporski, J.K., Steele, A., Westall, F., Thomas-Keprta, K.L., and McKay, D.S. (2002) Astrobiology 2 (1), 1-26.

Werne, J.P., Hollander, D.J., Behrens, A., Schaeffer, P., Albrecht, P., and Sinninghe Damste, J.S. (2000) Timing of early diagenetic sulfurization of organic matter: A precursor-product relationship in Holocene sediments of the anoxic Cariaco Basin, Venezuela. Geochim. Cosmochim. Acta 64 (10), 1741-1751.

Ueno, Y, Yoshioka, H., Maruyama, S., and Isozaki, Y. (2004) Carbon isotopes and petrography of kerogens in $\sim 3.5$ Ga hydrothermal silica dikes in the North Pole area, Western Australia. Geochim. Cosmochim. Acta 68 (3), 573-589. 
TABLE 1. NITROGEN TO CARBON RATIOS

\begin{tabular}{lcc|cc}
\hline \multicolumn{2}{c|}{ Sample } & \multicolumn{2}{c}{ Measured $\mathrm{CN}^{-} / \mathrm{C}^{-}$} & \multicolumn{2}{c}{ Calibrated N/C (Atomic) } \\
\hline Kerogen Standard & $0.023 \pm 0.009$ & \multicolumn{2}{c}{$0.018 \pm 0.067$} \\
\hline & Minimum & Maximum & Minimum & Maximum \\
Filaments & $0.02 \pm 0.008$ & $0.04 \pm 0.016$ & $(0.46 \pm 0.18) 10^{-3}$ & $(0.92 \pm 0.36) 10^{-3}$ \\
Spheroids & $0.12 \pm 0.047$ & $0.22 \pm 0.086$ & $(2.76 \pm 1.08) 10^{-3}$ & $(5.06 \pm 1.98) 10^{-3}$ \\
Laminae & $0.12 \pm 0.047$ & $1.00 \pm 0.039$ & $(2.76 \pm 1.08) 10^{-3}$ & $(23.0 \pm 9.00) 10^{-3}$ \\
\hline
\end{tabular}




\section{FIGURE CAPTIONS}

FIG. 1. Spheroidal organic microfossils in a polished thin section of chert from the $\sim$ 0.85 Ga Bitter Springs Formation. A: Optical photomicrograph in transmitted light. B-F: NanoSIMS element maps of the same area as in (A). Arrows show corresponding cells in the different figures. Scale in (A) applies to all. ${ }^{12} \mathrm{C}=$ carbon; ${ }^{12} \mathrm{C}^{14} \mathrm{~N}=$ nitrogen measured as $\mathrm{CN}^{-}$ion; ${ }^{32} \mathrm{~S}=$ sulfur; ${ }^{28} \mathrm{Si}=$ silicon; ${ }^{18} \mathrm{O}=$ oxygen

FIG. 2. Spheroidal organic microfossils in a polished thin section of chert from the Bitter Springs Formation. A: Optical photomicrograph in transmitted light, indicating area sputtered in the NanoSIMS (dotted oval). B: NanoSIMS map, illustrating image after sputtering to a lower plane of investigation. Arrows show corresponding cells in (A) and (B) and in Fig. 1. Focal plane is slightly below that in Fig. 1A. ${ }^{12} \mathrm{C}=$ carbon.

FIG. 3. Filamentous microfossils in a polished thin section of chert from the Bitter Springs Formation. A-C: Optical photomicrographs in transmitted light; (B) and (C) are at lower magnifications to illustrate the tube-like morphology and intertwined habit of these fossils; (C) is at a significantly lower focal plane than (A) and (B). D-F: NanoSIMS maps. Arrows show corresponding cells in the 
different figures. ${ }^{12} \mathrm{C}=$ carbon; ${ }^{12} \mathrm{C}^{14} \mathrm{~N}=$ nitrogen measured as $\mathrm{CN}^{-}$ion; ${ }^{32} \mathrm{~S}=$ sulfur.

FIG. 4. NanoSIMS images of a wall contact between two spheroidal microfossils in chert from the Bitter Springs Formation. A and B: Relatively low magnification maps. C-F: high resolution maps. White rectangle in (A) shows area of high resolution images in (C-F). Arrows in (E and F) tie locations of the silicon globules in $(\mathrm{F})$ with corresponding locations on the carbon map in (E). Dotted white ovals in (E and F) are reference areas to tie the two images for comparison. ${ }^{12} \mathrm{C}=$ carbon; ${ }^{12} \mathrm{C}^{14} \mathrm{~N}=$ nitrogen measured as $\mathrm{CN}^{-}$ion; ${ }^{32} \mathrm{~S}=$ sulfur; ${ }^{28} \mathrm{Si}=$ silicon

FIG. 5. Filamentous microfossils in a polished thin section of chert from the Bitter Springs Formation. A: Optical photomicrograph in transmitted light. BF: High resolution NanoSIMS maps. Black rectangle in (A) shows area of detail in $(\mathrm{B}-\mathrm{F})$. Scale in $(\mathrm{B})$ applies to $(\mathrm{B}-\mathrm{F}) .{ }^{12} \mathrm{C}=$ carbon; ${ }^{12} \mathrm{C}^{14} \mathrm{~N}=$ nitrogen measured as $\mathrm{CN}^{-}$ion; ${ }^{32} \mathrm{~S}=$ sulfur; ${ }^{28} \mathrm{Si}=$ silicon; ${ }^{16} \mathrm{O}=$ oxygen.

FIG. 6. Organic lamina in a polished thin section of chert from the Bitter Springs Formation. A: Optical photomicrograph in transmitted light. B-F: Elemental maps as imaged by NanoSIMS of the area in (A). Arrows show 
reference points for comparison. The white ovals show the same region in (A F). Scale in (A) applies to all. ${ }^{12} \mathrm{C}=$ carbon; ${ }^{12} \mathrm{C}^{14} \mathrm{~N}=$ nitrogen measured as $\mathrm{CN}^{-}$ ion; ${ }^{32} \mathrm{~S}=$ sulfur; ${ }^{28} \mathrm{Si}=$ silicon; ${ }^{18} \mathrm{O}=$ oxygen.

FIG. 7. SEM and NanoSIMS comparison of organic lamina in a polished thin section of chert from the Bitter Springs Formation. White oval shows the same area in each image; arrows show corresponding structures. The dashed arrow illustrates a structure suggestive of a cross section of a filament; in NanoSIMS the structure is defined by $\mathrm{C}, \mathrm{CN}, \mathrm{S}, \mathrm{Si}$ and $\mathrm{O}$ enrichment (only $\mathrm{C}$ enrichment illustrated here; see Fig. 6 for other elemental maps); in the backscattered SEM, a faint hint of the same structure is seen, indicated by the dashed arrow. 

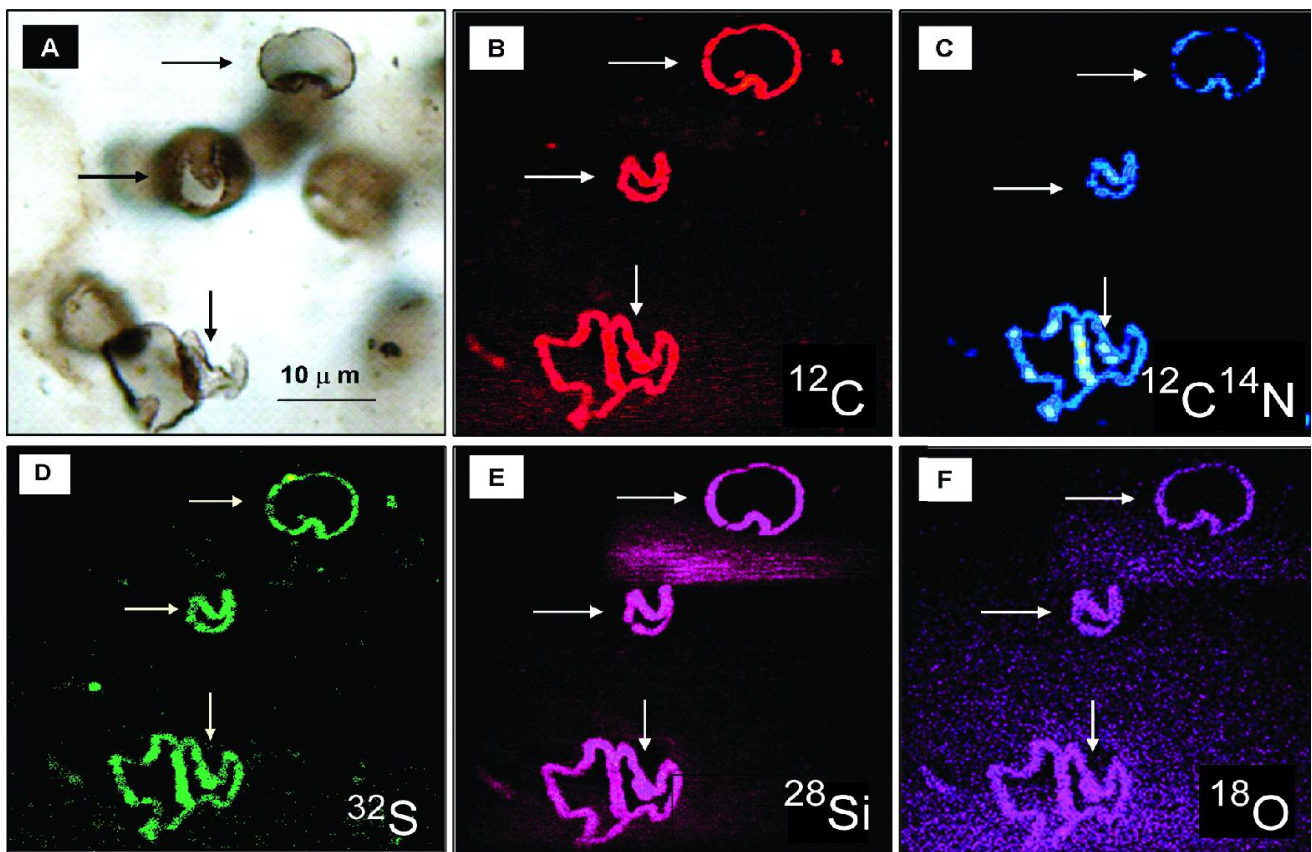

FIG. 1. Spheroidal organic microfossils in a polished thin section of chert from the $\sim 0.85$ Ga Bitter Springs Formation. A: Optical photomicrograph in transmitted light. B-F: NanoSIMS element maps of the same area as in (A). Arrows show corresponding cells in the different figures. Scale in (A) applies to all. ${ }^{12} \mathrm{C}=$ carbon; ${ }^{12} \mathrm{C}^{14} \mathrm{~N}=$ nitrogen measured as $\mathrm{CN}^{-}$ion; ${ }^{32} \mathrm{~S}=$ sulfur; ${ }^{28} \mathrm{Si}=$ silicon; ${ }^{18} \mathrm{O}=$ oxygen. 


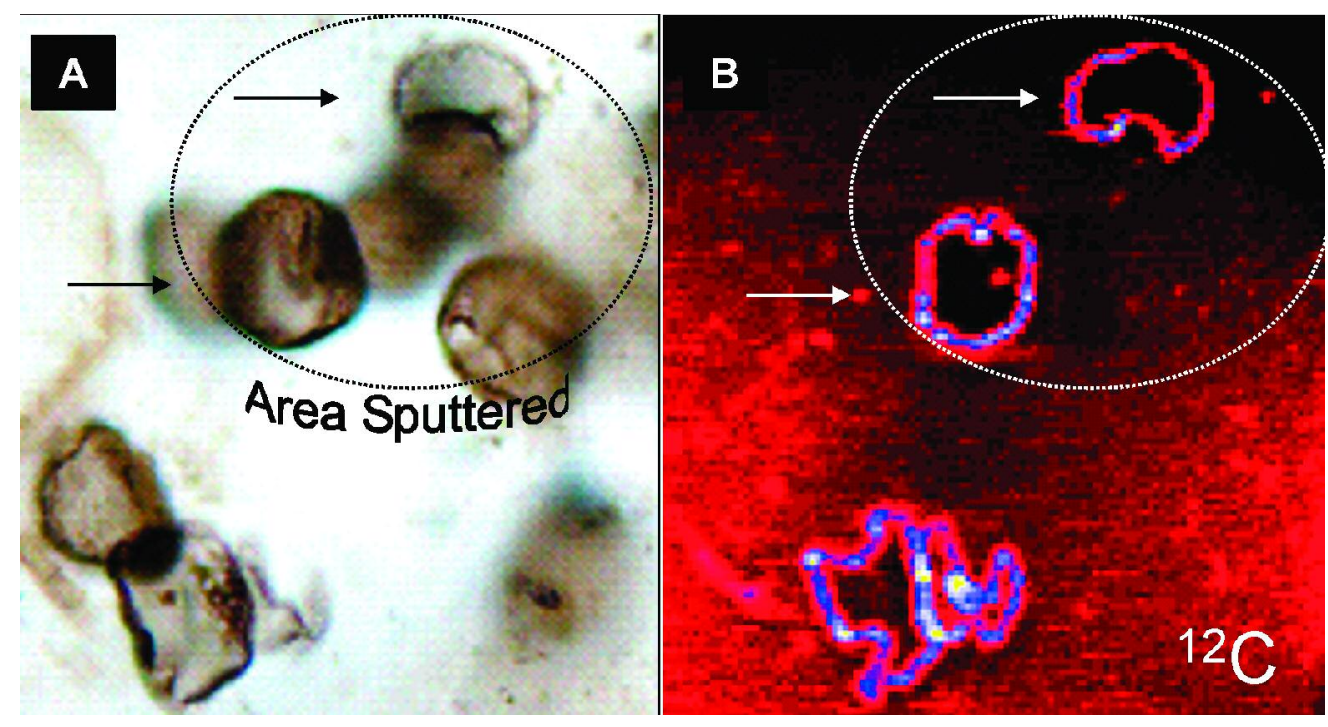

FIG. 2. Spheroidal organic microfossils in a polished thin section of chert from the Bitter Springs Formation. A: Optical photomicrograph in transmitted light, indicating area sputtered in the NanoSIMS (dotted oval). B: NanoSIMS map, illustrating image after sputtering to a lower plane of investigation. Arrows show corresponding cells in (A) and (B) and in Fig. 1. Focal plane is slightly below that in Fig. $1 \mathrm{~A} \cdot{ }^{12} \mathrm{C}=$ carbon. 

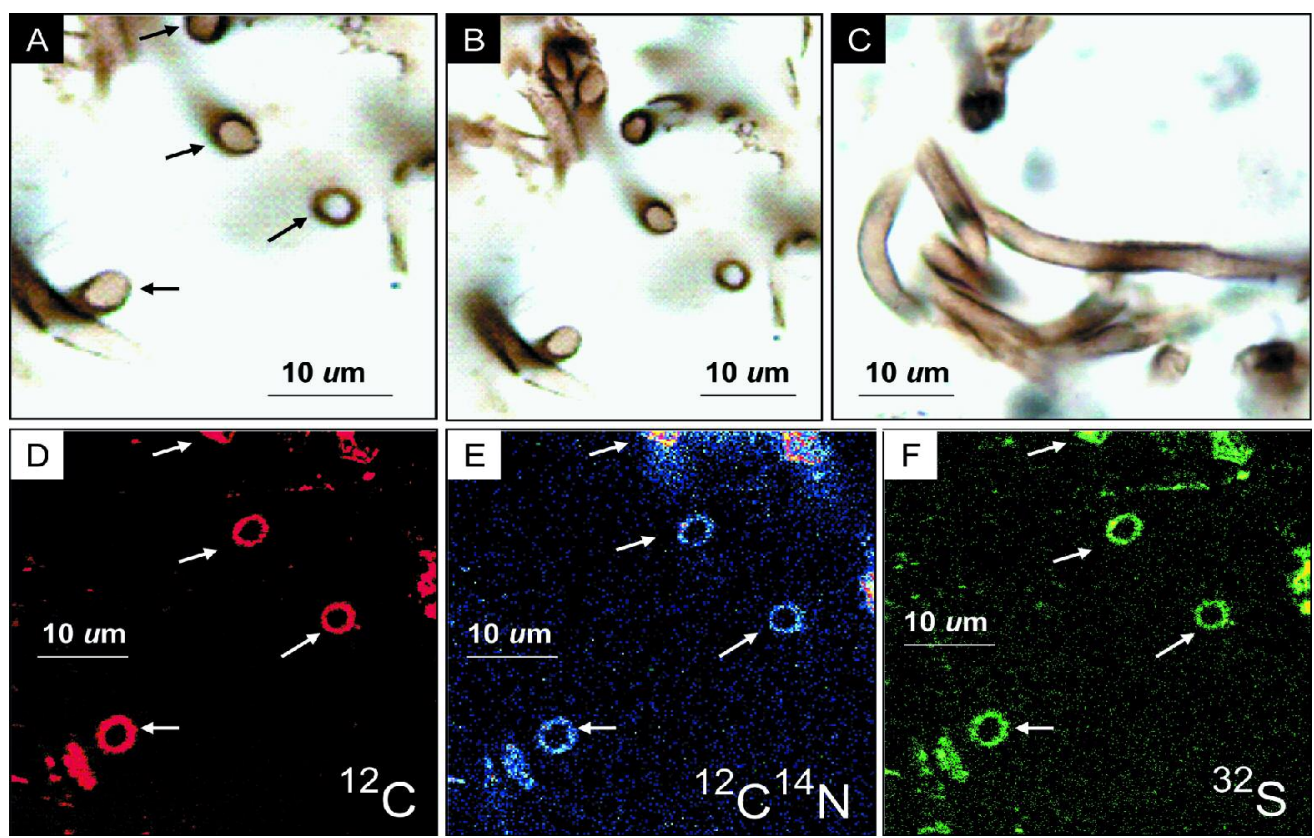

FIG. 3. Filamentous microfossils in a polished thin section of chert from the Bitter Springs Formation. A-C: Optical photomicrographs in transmitted light; (B) and (C) are at lower magnifications to illustrate the tube-like morphology and intertwined habit of these fossils; (C) is at a significantly lower focal plane than (A) and (B). D-F: NanoSIMS maps. Arrows show corresponding cells in the different figures. ${ }^{12} \mathrm{C}=$ carbon; ${ }^{12} \mathrm{C}^{14} \mathrm{~N}=$ nitrogen measured as $\mathrm{CN}^{-}$ion; ${ }^{32} \mathrm{~S}=$ sulfur. 

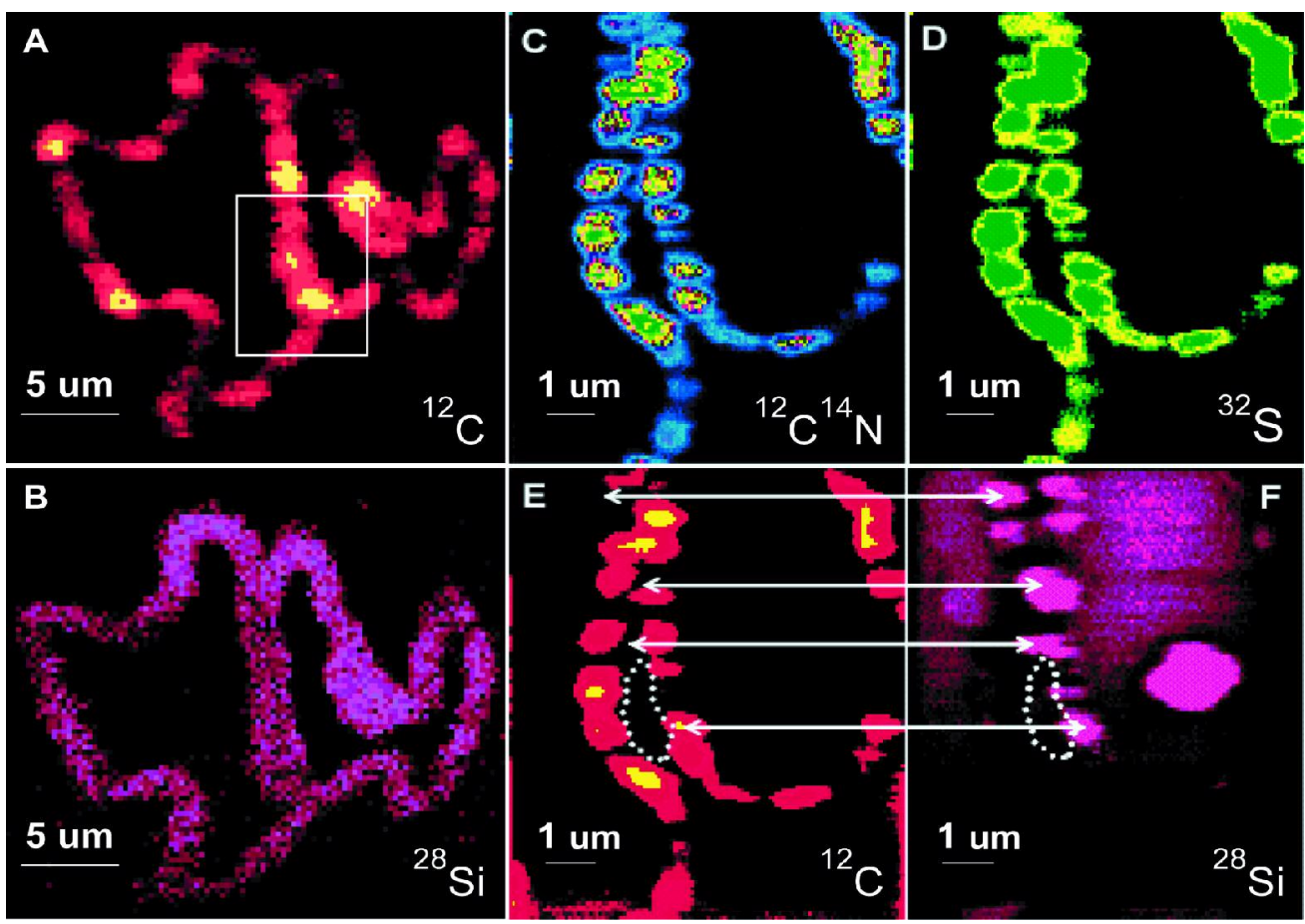

FIG. 4. NanoSIMS images of a wall contact between two spheroidal microfossils in chert from the Bitter Springs Formation. A and B: Relatively low magnification maps. C-F: high resolution maps. White rectangle in (A) shows area of high resolution images in (C-F). Arrows in ( $E$ and $F$ ) tie locations of the silicon globules in (F) with corresponding locations on the carbon map in (E). Dotted white ovals in ( $E$ and $F$ ) are reference areas to tie the two images for comparison. ${ }^{12} \mathrm{C}=$ carbon; ${ }^{12} \mathrm{C}^{14} \mathrm{~N}=$ nitrogen measured as $\mathrm{CN}^{-}$ion; ${ }^{32} \mathrm{~S}=$ sulfur; ${ }^{28} \mathrm{Si}=$ silicon. 

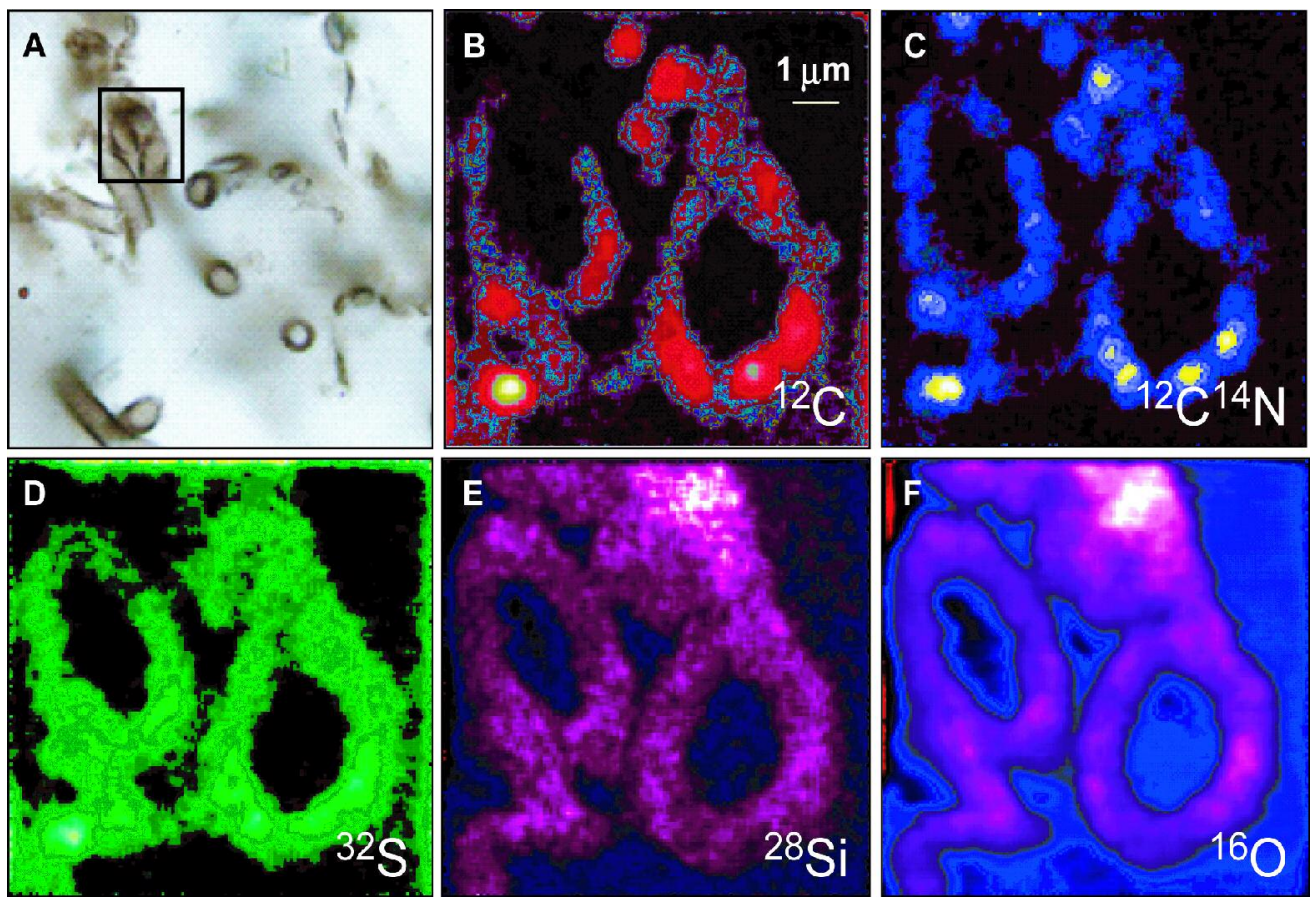

FIG. 5. Filamentous microfossils in a polished thin section of chert from the Bitter Springs Formation. A: Optical photomicrograph in transmitted light. B-F: High resolution NanoSIMS maps. Black rectangle in (A) shows area of detail in (B-F). Scale in (B) applies to (B-F). ${ }^{12} \mathrm{C}=$ carbon; ${ }^{12} \mathrm{C}^{14} \mathrm{~N}=$ nitrogen measured as $\mathrm{CN}^{-}$ion; ${ }^{32} \mathrm{~S}=$ sulfur; ${ }^{28} \mathrm{Si}=$ silicon; ${ }_{16} \mathrm{O}=$ oxygen. 

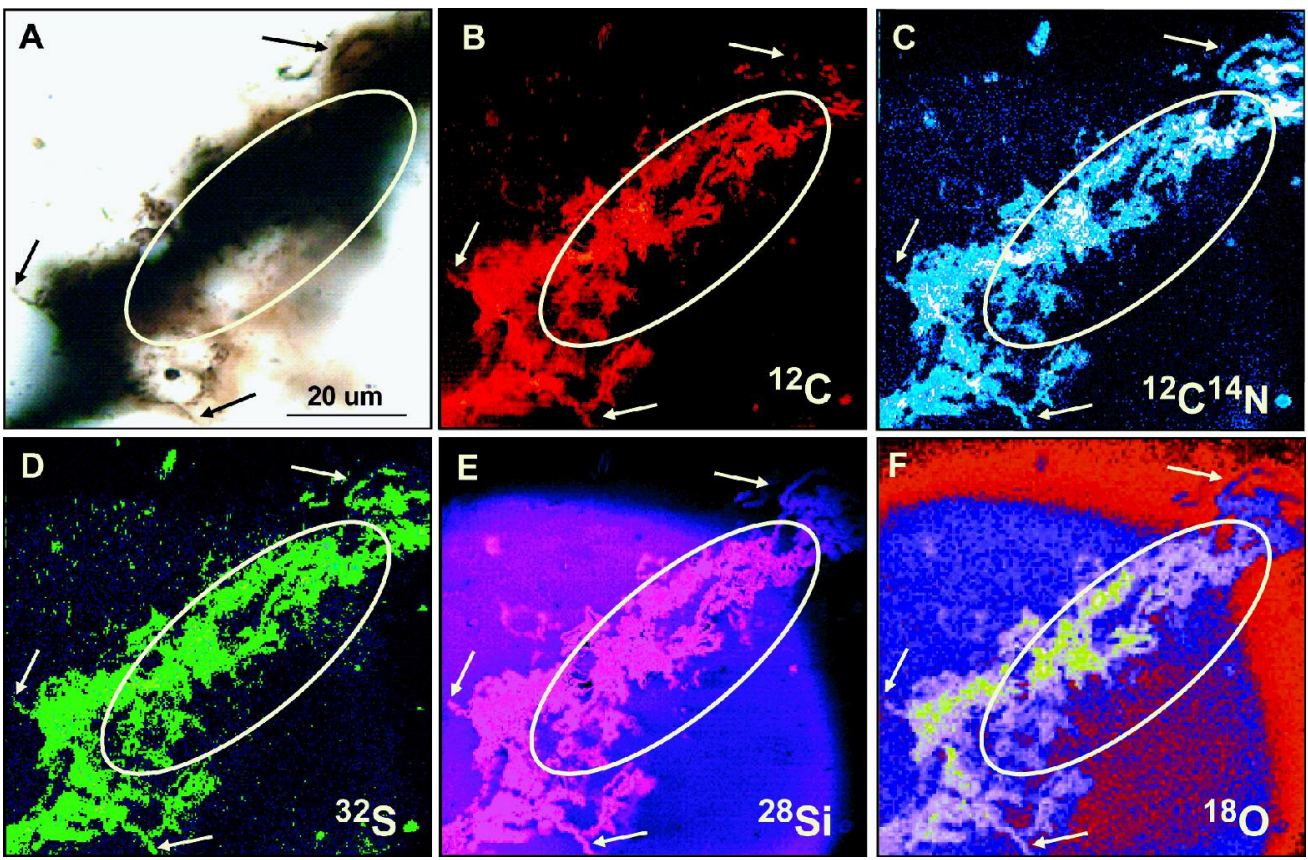

FIG. 6. Organic lamina in a polished thin section of chert from the Bitter Springs Formation. A: Optical photomicrograph in transmitted light. B-F: Elemental maps as imaged by NanoSIMS of the area in (A). Arrows show reference points for comparison. The white ovals show the same region in $(A-F)$. Scale in $(A)$ applies to all. ${ }^{12} C=$ carbon; ${ }^{12} \mathrm{C}^{14} \mathrm{~N}=$ nitrogen measured as $\mathrm{CN}^{-}$ion; ${ }^{32} \mathrm{~S}=$ sulfur; ${ }^{28} \mathrm{Si}=$ silicon; ${ }^{18} \mathrm{O}=$ oxygen. 

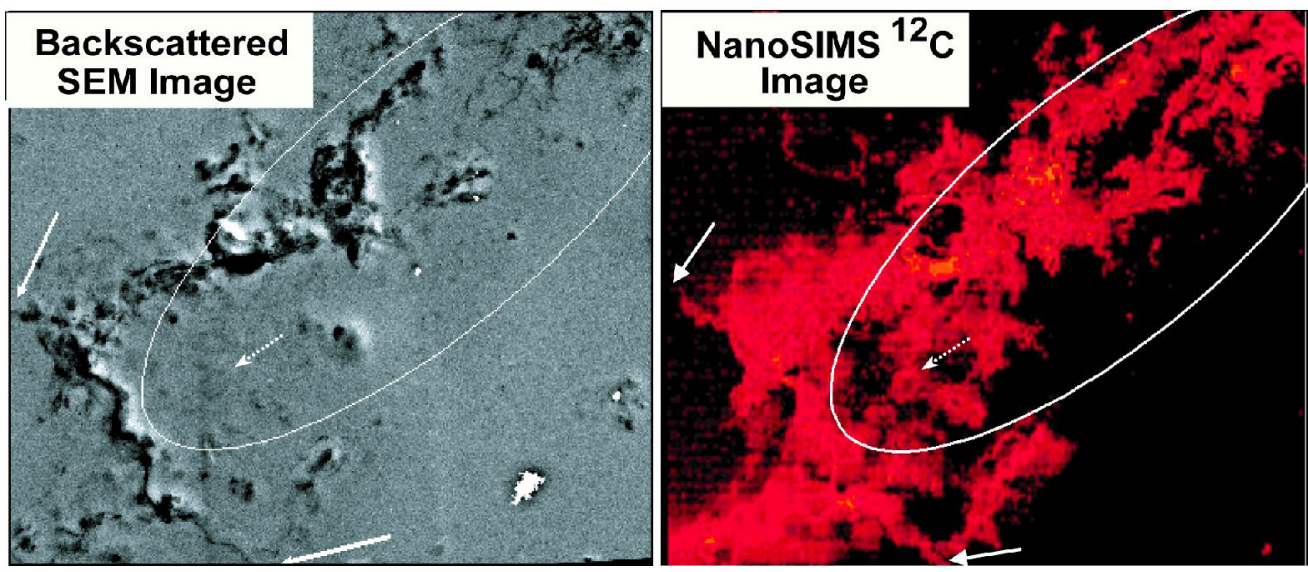

FIG. 7. SEM and NanoSIMS comparison of organic lamina in a polished thin section of chert from the Bitter Springs Formation. White oval shows the same area in each image; arrows show corresponding structures. The dashed arrow illustrates a structure suggestive of a cross section of a filament; in NanoSIMS the structure is defined by $\mathrm{C}, \mathrm{CN}$, S, Si and $\mathrm{O}$ enrichment (only C enrichment illustrated here; see Fig. 6 for other elemental maps); in the backscattered SEM, a faint hint of the same structure is seen, indicated by the dashed arrow. 